GRASAS Y ACEITES, 64 (5),

OCTUBRE-DICIEMBRE, 489-496, 2013

ISSN: 0017-3495

Dol: $10.3989 /$ gya.133112

\title{
Optimization of the protein concentration process from residual peanut oil-cake
}

\author{
By M.F. Gayol ${ }^{1, \otimes}$, M.C. Pramparo ${ }^{1}$, V. Nepote ${ }^{2}$, H. Fernandez ${ }^{3}$ and N.R. Grosso ${ }^{4}$ \\ ${ }^{1}$ Facultad de Ingeniería, UNRC, Río Cuarto, Córdoba, Argentina \\ ${ }^{2}$ ICTA, Facultad de Ciencias Exactas, Físicas y Naturales (UNC), IMBIV-CONICET, Córdoba, Argentina \\ ${ }^{3}$ Facultad de Ciencias Exactas, UNRC, Río Cuarto, Córdoba, Argentina \\ ${ }^{4}$ Química Biológica, Facultad de Ciencias Agropecuarias (UNC), IMBIV-CONICET, Córdoba, Argentina \\ $\bowtie$ Corresponding author: mgayol@ing.unrc.edu.ar
}

\section{RESUMEN}

Optimización del proceso de preparación de concentrado de proteína de la torta residual de maní

El objetivo de este trabajo fue encontrar las mejores condiciones para obtener un concentrado de proteínas a partir de la torta residual de maní (POC). El estudio se llevó a cabo en POC provenientes de la extracción industrial de aceite de maní. Se utilizaron distintas condiciones para la extracción y precipitación de proteínas: relación agua / harina (10:1, 20:1 y $30: 1), \mathrm{pH}$ de extracción (8, 9 y 10), concentración de $\mathrm{NaCl}$ (0 y $0,5 \mathrm{M})$, tiempo de extracción (30, 60 y $120 \mathrm{~min}$ ), temperatura $\left(25,40\right.$ y $\left.60^{\circ} \mathrm{C}\right)$, número de etapas de extracción (1, 2 y 3 ), y el $\mathrm{pH}$ de precipitación (4, 4,5 y 5). Las condiciones de extracción y de precipitación que mostraron mayor rendimiento de proteína fueron: relación de 10:1 en agua / harina, $\mathrm{pH}$ de extracción de 9 , en ausencia de $\mathrm{NaCl}, 2$ etapas de extracción de 30 min cada una a $40^{\circ} \mathrm{C}$ y el pH de precipitación de 4,5. En estas condiciones, el concentrado de proteína de maní (PC) fue de $86,22 \%$, mientras que el porcentaje de proteínas de la POC inicial fue de $38,04 \%$. Las POC son una fuente alternativa de proteínas que pueden ser utilizadas para el consumo humano o la alimentación animal. De esta manera, se le puede dar un valor agregado extra a un residuo de la industria del aceite del maní.

PALABRAS CLAVE: Concentrado - Maní - Proteína Torta Residual.

\section{SUMMARY}

Optimization of the protein concentration process from residual peanut oil-cake

The objective of this study was to find the best process conditions for preparing protein concentrate from residual peanut oil-cake (POC). The study was carried out on POC from industrial peanut oil extraction. Different protein extraction and precipitation conditions were used: water/ flour ratio $(10: 1,20: 1$ and $30: 1), \mathrm{pH}(8,9$ and 10), $\mathrm{NaCl}$ concentration $(0$ and $0.5 \mathrm{M})$, extraction time (30, 60 and 120 $\mathrm{min})$, temperature $\left(25,40\right.$ and $\left.60^{\circ} \mathrm{C}\right)$, extraction stages $(1$, 2 and 3$)$, and precipitation $\mathrm{pH}(4,4.5$ and 5). The extraction and precipitation conditions which showed the highest protein yield were 10:1 water/flour ratio, extraction at $\mathrm{pH} 9, \mathrm{no} \mathrm{NaCl}$, 2 extraction stages of $30 \mathrm{~min}$ at $40^{\circ} \mathrm{C}$ and precipitation at $\mathrm{pH}$ 4.5. Under these conditions, the peanut protein concentrate (PC) contained $86.22 \%$ protein, while the initial POC had $38.04 \%$. POC is an alternative source of protein that can be used for human consumption or animal nutrition. Therefore, it adds value to an industry residue.

KEY-WORDS: Concentrate - Oil-cake - Peanut -
Protein.

\section{INTRODUCTION}

Peanuts are characterized by high oil and protein content and by low percentages of carbohydrates and ash. Peanut seed contains approximately 47$52 \%$ oil and $25-30 \%$ protein (Grosso and Guzmán, 1995).

Previous research has shown that peanut seeds are a potential source of food-grade protein for the fortification of food products. Such protein could be concentrated from residual cakes and flours through industrially applicable techniques (Rhee et al., 1972, 1973; Quinn and Beuchat, 1975; Kim et al., 1992; Yu et al., 2007).

The amino acid profile of peanut residual flours showed that it could be an ingredient for protein fortification ( $\mathrm{Yu}$ et al., 2007). Peanut protein concentrates were obtained using raw and roasted, fermented and unfermented peanut flours ( $\mathrm{Yu}$ et al., 2007). These authors obtained peanut protein concentrates with $85 \%$ protein versus $50 \%$ protein in the defatted peanut flour.

Partially defatted peanut flour is an inexpensive and underutilized by-product from the peanut oil industry which is rich in protein and offers the same health and dietary benefits of peanuts but with less fat. Thus, in countries like Argentina, where peanut protein is available in abundance, it could replace animal proteins for product formulation. In Argentina, the annual peanut production is about 900,000 Tns, and nearly $30 \%$ of the total peanut production is used for oil extraction, leaving a large amount of residue in the form of peanut oil cake (Fiant et al., 2012).

There is limited information available in the literature on the peanut protein concentration process from residual oil-cake. The extraction and precipitation $\mathrm{pH}$, extraction temperature, time and 
number of extraction stages, and concentration of $\mathrm{NaCl}$ are important factors to be considered in the protein extraction process (Kim et al., 1992; Johnson and Kikuchi, 2004; Lopes Barbosa et al., 2006; Yu et al., 2007).

Peanut oil-cake is a by-product from the oil extraction industry. The process consists of the following steps: a) lamination, b) cooking at $110^{\circ} \mathrm{C}, \mathrm{c}$ ) pressing, d) solvent extraction (hexane), and e) solvent elimination process (Cheftel and Cheftel, 2000). This raw material is very hard to be treated and has never been used to study different extraction conditions for producing a high quality protein concentrate. The concentration of proteins from this material could increase its value; and it could become a source of new protein with applications in different industries and processes. Therefore, the objective of this study was to find the best processing conditions for the preparation of protein concentrate from residual peanut oilcake.

\section{MATERIALS AND METHODS}

\subsection{Materials}

Peanut oil-cake (POC) is a residue obtained from industrial peanut oil production after pressing and solvent extraction of peanut kernels. POC was provided by the company Lorenzati- Ruescht y Cia from Ticino, Córdoba, Argentina in 2011.

\subsection{Methods}

\subsubsection{Peanut oil-cake pre-treatment}

POC was ground to flour until a homogenous particle size was obtained (sieve Mesh 0,75 mm). The flour was divided into two samples: peanut oilcake flour $(P)$ and peanut oil-cake flour extracted with $70 \%$ ethanol (EP). The EP sample was obtained by two stages of solid-liquid extraction of $50 \mathrm{~g} \mathrm{P}$ with $150 \mathrm{~mL} 70 \%$ ethanol (in water, v/v) in order to eliminate soluble carbohydrates (Conkerton and Ory, 1976). This sample was dried in the oven at $60^{\circ} \mathrm{C}$ for $2 \mathrm{~h}$.

\subsubsection{Protein extraction and precipitation}

Proteins from $P$ and EP samples $(5 \mathrm{~g})$ were extracted at different conditions with distilled aqueous solutions at different $\mathrm{pH}$ using a magnetic shaker. The different extraction conditions were: water/flour ratio $(10: 1,20: 1$ and $30: 1, \mathrm{v} / \mathrm{w}$ respectively), extraction $\mathrm{pH}(8,9$ and 10, adjusted with $1 \mathrm{M} \mathrm{NaOH}), \mathrm{NaCl}$ concentration ( 0 and $0.5 \mathrm{M}$ ), extraction time $(30,60$ and $120 \mathrm{~min})$, temperature $\left(25,40\right.$ and $\left.60^{\circ} \mathrm{C}\right)$ and number of extraction stages (1, 2 and 3$)$. The obtained slurries were centrifuged at $12,000 \mathrm{~g}$ for $20 \mathrm{~min}$ at $25^{\circ} \mathrm{C}$ in a Beckman Coulter Allegra ${ }^{\mathrm{TM}}$ 25R centrifuge (Germany) in order to eliminate residual flour.
Proteins were precipitated from the obtained suspensions at different $\mathrm{pH}: 4,4.5$, and 5 and adjusted with $1 \mathrm{M} \mathrm{HCl}$. Then, the extract was centrifuged at $12,000 \mathrm{~g}$ for $20 \mathrm{~min}\left(25^{\circ} \mathrm{C}\right)$. The precipitate was analyzed for concentrate yield (g dry weight of the concentrate per $100 \mathrm{~g}$ flour), protein content in the concentrate ( $g$ protein per $100 \mathrm{~g}$ concentrate) and protein yield (g protein in the concentrate per $100 \mathrm{~g}$ flour).

\subsubsection{Chemical composition of peanut oil-cake and protein isolates}

Moisture, lipids, ashes and protein contents in POC and PC were determined by the AOAC methods (AOAC, 1995). The nitrogen content was converted to protein percentage using the conversion factor 5.46. The carbohydrate content was estimated by the difference of the other components using the following formula: carbohydrate content $=100 \%-(\%$ protein $+\%$ oil + $\%$ ash) (Gayol et al., 2010).

\subsubsection{Amino acid profile}

The amino acid composition was determined by high performance liquid chromatography (Alonso et al., 1994) using a chromatograph Perkin Elmer (Waltham, Massachusetts, USA), series 200, equipped with a UV-visible detector and a Microsorb-mv 100-5 C18 $(250 \times 4.6 \mathrm{~mm})$ column.

\subsubsection{Statistical analyses}

The experiment was carried out in three repetitions. Data were analyzed using the InfoStat software, version 2011p (Facultad de Ciencias Agropecuarias, Universidad Nacional de Córdoba). Means and standard deviations were calculated. Simple and factorial analysis of variance and the LSD test were used to detect significant differences $(\alpha=0.05)$.

\section{RESULTS AND DISCUSSION}

\subsection{Protein extraction and precipitation conditions}

\subsubsection{Water/flour ratio}

Three water/flour ratios (10:1, 20:1 and 30:1, $\mathrm{v} / \mathrm{w})$ were tested for protein extraction from $\mathrm{P}$ and EP under the following conditions: $\mathrm{pH}=9,25^{\circ} \mathrm{C}$, shaking for $60 \mathrm{~min}$. There were no significant differences in protein yields among the water/ flour ratios tested. Under these conditions, protein yields were between $12-14 \mathrm{~g}$ protein $100 \mathrm{~g}^{-1}$ peanut flour. Therefore, the lower water/flour ratio (10:1) was chosen in successive tests. The same water/ flour ratio was used by Kim et al. (1992) to obtain protein isolates from nine peanut cultivars. $\mathrm{Yu}$ et 
al. (2007) working on fermented and unfermented peanut flour and using a 10:1 - 100:1 water/flour ratio range $(\mathrm{pH}=10$, shaking for $60 \mathrm{~min}$ at room temperature), found a water/flour ratio of $20: 1$ for the optimum peanut protein recovery. The water/ flour ratio of 50:1 yielded about the same amount of protein as the ratio $20: 1$; however, to remove excess water the $20: 1$ ratio is more cost effective.

\subsection{2. $\mathrm{pH}$ and $\mathrm{NaCl}$ concentration for protein extraction}

The concentrate and protein yield results after protein extraction from flour samples (P and EP) at different $\mathrm{pH}$ and $\mathrm{NaCl}$ conditions are presented in Table 1. Samples were processed in one extraction stage with a 10 water/flour ratio by shaking for $60 \mathrm{~min}$ at $25^{\circ} \mathrm{C}$. After extraction, the protein was precipitated at $\mathrm{pH} 4.5$.

Data were analyzed by factorial ANOVA (factors: sample, extraction $\mathrm{pH}$, and $\mathrm{NaCl}$ concentration). Significant effects on the "concentration yield" variable after protein extraction were found for all of these factors and in the interactions "sample $\times \mathrm{pH}^{\text {", }}$ "sample $\times \mathrm{NaCl}$ ", and "pH $\times \mathrm{NaCl}$ ". The maximum concentrate yields (between 16.04-16.98\%) were observed when $\mathrm{P}$ and EP where extracted at either $\mathrm{pH} 9$ or 10 , in the absence of $\mathrm{NaCl}$.

Another variable included in Table 1 was the protein content in the concentrates. Sample and $\mathrm{NaCl}$ were the only factors with significant effects on this variable. In general, the average protein contents were higher in the concentrates from EP with $0.5 \mathrm{M} \mathrm{NaCl}$ than from $\mathrm{P}$ with no $\mathrm{NaCl}$. The $\mathrm{pH}$ factor did not show a significant effect on the protein content in the concentrate. The concentrate with the highest protein content $(88.38 \%)$ was obtained from EP at $\mathrm{pH} 9$ and $0.5 \mathrm{M} \mathrm{NaCl}$. However, significant differences were not found for the protein content with respect to the concentrate obtained from $\mathrm{P}$ under the same conditions $(\mathrm{pH} 9$ and $0.5 \mathrm{M} \mathrm{NaCl}$ ).

The last variable studied (Table 1) was the protein yield after the flour sample extractions. The sample factors, $\mathrm{pH}$, and $\mathrm{NaCl}$ and the interactions "sample $\times \mathrm{NaCl}$ ", and "pH $\times \mathrm{NaCl}$ " showed significant effects on the protein yield variable. The maximum protein yield were obtained when the $P$ and EP samples were extracted at $\mathrm{pH} 9$ or 10 , in the absence of $\mathrm{NaCl}$, with no significant differences between them.

Considering the obtained results, a washing in the peanut flour with $70 \%$ ethanol may not be necessary since no significant increase has been obtained in the final protein yield. In addition, the extraction yield of $P$ with $70 \%$ ethanol was $7.31 \%$. $P$ and EP had $38.04 \%$ and $36.26 \%$, respectively, and the ethanolic extract had $10.57 \%$ proteins, which indicates that washing peanut flour samples with $70 \%$ ethanol not only extracted soluble compounds such as carbohydrates but also could have extracted some soluble proteins.

The extraction of $\mathrm{P}$ at $\mathrm{pH} 9$ and 10 showed higher concentrations and protein yields than at $\mathrm{pH}$ 8. The percentages of proteins recovered from POC were $35.12 \%$ and $32.75 \%$ (g of protein in the

Table 1

Concentrate and protein yields of protein extracts obtained from peanut flour samples (P and EP) extracted at different $\mathrm{pH}$ and $\mathrm{NaCl}$ concentrations. Protein extraction conditions: 10:1 water/flour ratio, one extraction stage, shaking for $60 \mathrm{~min}, 25^{\circ} \mathrm{C}$, and $\mathrm{pH} 4.5$ for protein precipitation

\begin{tabular}{|c|c|c|c|c|c|}
\hline Flour sample $^{a}$ & $\begin{array}{c}\text { Extraction } \\
\text { pH }\end{array}$ & $\mathrm{NaCl}(\mathrm{M})$ & Concentrate yield ${ }^{\mathrm{b} *}$ & $\begin{array}{l}\text { Protein content in } \\
\text { the concentrate }{ }^{c^{*}}\end{array}$ & Protein yield ${ }^{d^{*}}$ \\
\hline $\mathrm{P}$ & 8 & 0.5 & $8.03 \pm 0.44 d$ & $78.43 \pm 6.03 b c$ & $6.48 \pm 0.98 d$ \\
\hline$P$ & 8 & 0 & $10.64 \pm 0.45 c$ & $78.44 \pm 5.77 b c$ & $9.16 \pm 1.43 b c$ \\
\hline $\mathrm{P}$ & 9 & 0.5 & $8.53 \pm 0.43 d$ & $82.03 \pm 4.10 a b c$ & $7.01 \pm 0.35 \mathrm{~cd}$ \\
\hline $\mathrm{P}$ & 9 & 0 & $16.66 \pm 0.83 a$ & $80.23 \pm 3.81 b c$ & $13.36 \pm 1.83 a$ \\
\hline$P$ & 10 & 0.5 & $9.52 \pm 0.48 \mathrm{~cd}$ & $79.53 \pm 5.63 \mathrm{bc}$ & $7.57 \pm 0.38 \mathrm{bcd}$ \\
\hline $\mathrm{P}$ & 10 & 0 & $16.08 \pm 0.80 a$ & $77.50 \pm 2.25 c$ & $12.46 \pm 1.28 \mathrm{a}$ \\
\hline EP & 8 & 0.5 & $2.99 \pm 0.15 f$ & $84.21 \pm 3.13 a b$ & $2.52 \pm 0.13 f$ \\
\hline EP & 8 & 0 & $12.62 \pm 0.05 b$ & $78.96 \pm 5.03 b c$ & $9.44 \pm 0.52 b$ \\
\hline EP & 9 & 0.5 & $4.03 \pm 0.20 f$ & $88.38 \pm 3.42 \mathrm{a}$ & $3.56 \pm 0.18$ ef \\
\hline EP & 9 & 0 & $16.04 \pm 0.80 a$ & $80.98 \pm 4.02 b c$ & $12.89 \pm 0.90 a$ \\
\hline EP & 10 & 0.5 & $6.33 \pm 0.37 \mathrm{e}$ & $84.08 \pm 4.20 a b$ & $5.32 \pm 0.31 \mathrm{de}$ \\
\hline EP & 10 & 0 & $16.98 \pm 0.85 a$ & $80.98 \pm 4.05 b c$ & $13.75 \pm 1.71 \mathrm{a}$ \\
\hline
\end{tabular}

${ }^{a}$ Peanut flour samples: $\mathrm{P}=$ peanut oil-cake flour and EP = peanut oil cake flour extracted with $70 \%$ ethanol solution.

${ }^{\mathrm{b}}$ Concentrate yield: $\mathrm{g}$ isolate $100 \mathrm{~g}^{-1}$ flour.

${ }^{c}$ Protein content in the concentrate: $\mathrm{g}$ proteins $100 \mathrm{~g}^{-1}$ concentrate.

d Protein yield: $g$ proteins $100 \mathrm{~g}^{-1}$ flour.

* Means and standard deviations followed by different letters in each column indicate significant differences (ANOVA, LSD test, $\alpha=0.05)$. 
concentrate per $100 \mathrm{~g}$ of protein in the flour) for different $\mathrm{pH}$ extraction ( $\mathrm{pH} 9$ and 10, respectively).

The addition of $0.5 \mathrm{M} \mathrm{NaCl}$ had a slightly positive effect on the protein purity of concentrates, but negatively affected protein yield.

Rhee et al. (1973) and Basha and Cherry (1976) reported that the largest amounts of soluble proteins extracted in water and sodium phosphate buffer were at $\mathrm{pH} 9$ and 10. At $\mathrm{pH}$ values above 10, protein levels in different extraction media decreased slightly as a result of alkaline denaturation. Natarajan et al. (1975) reported that peanut proteins are known to be soluble at $\mathrm{pH}<2$ and $\mathrm{pH}>7$, and are very stable to heat treatment. Yu et al. (2007) found that the optimum peanut protein recovery was achieved at $\mathrm{pH}$ 10. The use of $\mathrm{pH}$ higher than 10 was not advisable because of undesirable changes such as protein denaturation and discoloration, which could affect the functionality and sensory quality of peanut protein concentrate. Liu et al (2012) obtained a concentrate (89\% protein) from defatted peanut flour at $\mathrm{pH} 8$ extraction.

In this study, the extraction and protein yields did not differ significantly at either $\mathrm{pH} 9$ or 10 . The conditions chosen for preparing protein concentrates from peanut oil- cake were those using peanut flour without washing with $70 \%$ ethanol, and extracting the protein at $\mathrm{pH} 9$ with no $\mathrm{NaCl}$.

\subsection{3. $\mathrm{pH}$ of protein precipitation}

The concentrate and protein yields after the peanut oil-cake flour $(\mathrm{P})$ extraction and precipitation at different $\mathrm{pH}(4.0,4.5$ and 5.0) are shown in Table 2. The protein extraction conditions were 10:1 water/flour ratio, one extraction stage, shaking for $60 \mathrm{~min}, \mathrm{pH} 9$, and $25^{\circ} \mathrm{C}$. The precipitate obtained at $\mathrm{pH} 4.5$ showed the highest values in concentrate and protein yields in comparison with the other $\mathrm{pH}$ conditions. The concentrates at $\mathrm{pH} 4.5$ and 5.0 had higher protein contents than that obtained at $\mathrm{pH}$ 4.0. The percentages of protein recovered from POC were $23.34 \%, 35.12 \%$, and $28.55 \%$ (g of protein in the concentrate per $100 \mathrm{~g}$ of protein in POC) for different protein precipitation $\mathrm{pH}(\mathrm{pH} 4$, 4.5 , and 5 , respectively).
Yu et al. (2007) worked at $\mathrm{pH} 4.0$ to separate the peanut protein from the supernatant by isoelectric precipitation because the peanut proteins appear to be less soluble at this $\mathrm{pH}$. Wu et al. (2009) found that 4.5 was the isoelectric $\mathrm{pH}$ for precipitation of peanut protein for preparing protein concentrates.

\subsubsection{Extraction time and number of extraction stages of proteins}

Protein content in the concentrate and protein yield after the extraction of peanut oil-cake flour $(P)$ using different extraction stages and shaking during different times are shown in Figure 1. The protein extraction conditions were: 10:1 water/flour ratio, $\mathrm{pH}$ 9, with no $\mathrm{NaCl}, 25^{\circ} \mathrm{C}$, and $\mathrm{pH} 4.5$ for protein precipitation.

The data were analyzed by two-way ANOVA (factors: number of extraction stages and extraction time). The number of stages factor was the only one that showed a significant effect on the variables studied, protein content in the concentrate and protein yield. The protein yield was higher in the first stage (between 10.34 and $11.66 \%$ ) than in the other stages. About $90 \%$ of total proteins were extracted in the first and second stages. The extraction time did not show a significant effect on the variables studied. As a consequence of these results, the extraction process chosen consisted of two extraction stages of $30 \mathrm{~min}$ each. Lopes Barbosa et al. (2006) reported that an increase in extraction time ( 1 and $3 \mathrm{~h}$ ) in defatted soy flour did not result in a higher protein yield.

\subsubsection{Extraction temperature of proteins from peanut oil-cake flour}

The results of the concentrate and protein yields after peanut oil-cake flour $(P)$ extraction obtained at different temperatures $\left(25,40\right.$ and $\left.60^{\circ} \mathrm{C}\right)$ are shown in Table 3. Proteins were extracted and precipitated at the following conditions: 10:1 water/flour ratio, two extraction stages, shaking for $30 \mathrm{~min}, \mathrm{pH} 9$, with no $\mathrm{NaCl}, 25^{\circ} \mathrm{C}$, and $\mathrm{pH} 4.5$ for protein precipitation. The percentages of proteins recovered from POC were $37.57 \%, 45.37 \%$, and $45.61 \%$ (g of protein

Table 2

Concentrate and protein yields of protein extracts obtained from peanut oil-cake flour $(\mathrm{P})$ extracted and precipitated at different $\mathrm{pH}$. Protein extraction conditions: 10:1 water/flour ratio, one extraction stage, shaking for $60 \mathrm{~min}, \mathrm{pH} \mathrm{9}$, and $25^{\circ} \mathrm{C}$

\begin{tabular}{|c|c|c|c|}
\hline Precipitation pH & Concentrate yield $^{\mathrm{a}}$ * & $\begin{array}{c}\text { Protein content } \\
\text { in the concentrate }\end{array}$ & Protein yield ${ }^{c}$ * \\
\hline 4.0 & $12.03 \pm 0.20 b$ & $73.82 \pm 2.05 c$ & $8.88 \pm 0.10 c$ \\
\hline 4.5 & $16.66 \pm 0.83 a$ & $80.23 \pm 3.81 a b$ & $13.36 \pm 1.83 \mathrm{a}$ \\
\hline 5.0 & $12.83 \pm 0.44 b$ & $86.76 \pm 1.88 a$ & $10.86 \pm 0.36 b$ \\
\hline
\end{tabular}

\footnotetext{
${ }^{a}$ Concentrate yield: $\mathrm{g}$ isolate $100 \mathrm{~g}^{-1}$ flour.

${ }^{b}$ Protein content in the concentrate: $\mathrm{g}$ proteins $100 \mathrm{~g}^{-1}$ concentrate.

${ }^{c}$ Protein yield: g proteins $100 \mathrm{~g}^{-1}$ flour.

* Means and standard deviations followed by different letters in each column indicate significant

differences (ANOVA, LSD test, $\alpha=0.05$ ).
} 


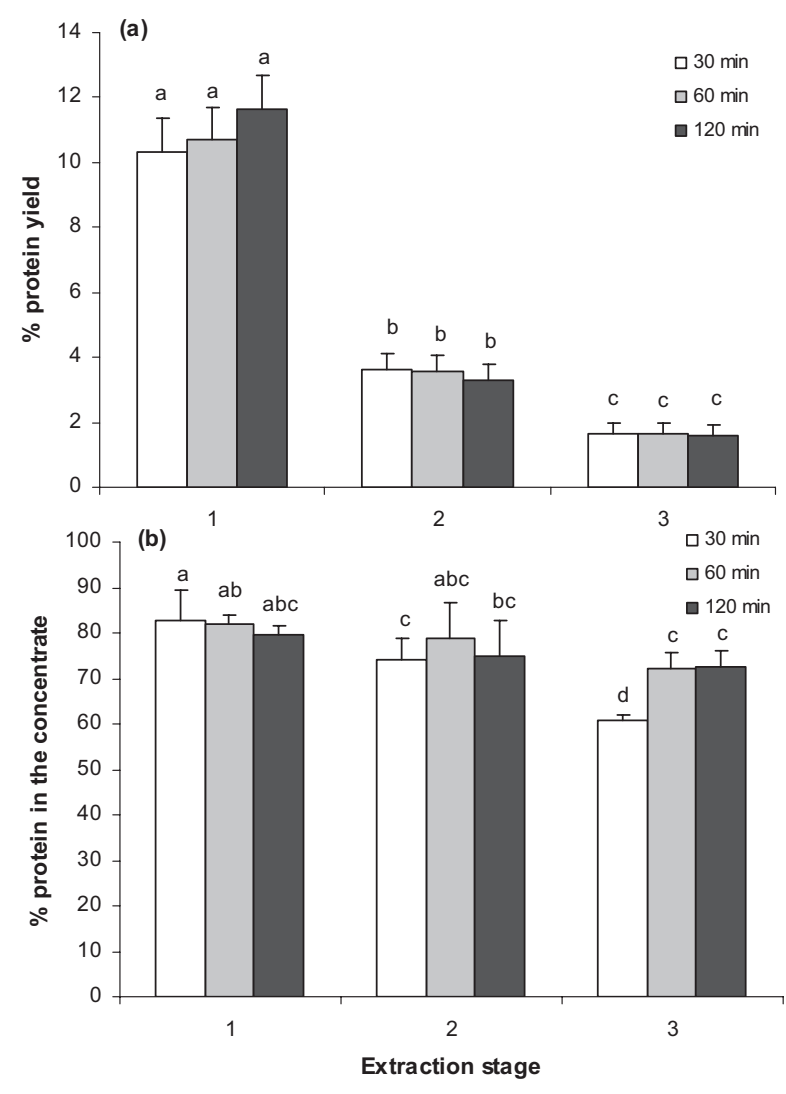

Figure 1

(a) Protein content in the concentrate and (b) protein yield of the protein extracts obtained from peanut oil-cake flour $(P)$ using different extraction stages and shaking during different times. Protein extraction conditions: $10: 1$ water/flour ratio, $\mathrm{pH} 9,25^{\circ} \mathrm{C}$, and $\mathrm{pH} 4.5$ for protein precipitation.

in the concentrate per $100 \mathrm{~g}$ of protein in POC) for different extraction temperatures $(25,40$ and $60^{\circ} \mathrm{C}$, respectively). The highest concentrate and protein yields were obtained at 40 and $60^{\circ} \mathrm{C}$ without significant differences between them. The protein content in the concentrate was higher at $40^{\circ} \mathrm{C}$. Lopes Barbosa et al. (2006) reported an increase in the efficiency of protein extraction in defatted soy flour, measuring 64 and $88 \%$ protein extracted at 4 and $50^{\circ} \mathrm{C}$, respectively. Johnson and
Kikuchi (2004) worked on temperatures between 27 and $66^{\circ} \mathrm{C}$ for the protein extraction of soy flour observing that the proteins became progressively less soluble at temperatures higher than $70^{\circ} \mathrm{C}$. In the present study, $40^{\circ} \mathrm{C}$ was the best extraction temperature for preparing peanut protein isolates from peanut oil-cake flour.

Ma et al. (2010), using response surface methodology, found the optimal parameter for the process of protein extraction from defatted peanut flour for primary and secondary extraction. They reported that the optimal values are 11.79:1 liquid/ solid ratio $(\mathrm{v} / \mathrm{w}), 36.35^{\circ} \mathrm{C}$ extraction temperature, and $85 \%$ ethanol concentration for the primary protein extraction; and 8:1 liquid/solid ratio (v/w), $38.40^{\circ} \mathrm{C}$ extraction temperature, and $97.5 \%$ ethanol concentration for the secondary protein extraction.

\subsection{Chemical composition of peanut oil-cake and protein concentrate}

The chemical composition of peanut oil-cake (POC) and protein concentrate (PC) from peanut oil-cake flour $(P)$ obtained at the optimum extraction and precipitation conditions (10 water/flour ratio, two extraction stages, shaking for $30 \mathrm{~min}, \mathrm{pH}$ 9, in the absence of $\mathrm{NaCl}, 40^{\circ} \mathrm{C}$, and $\mathrm{pH} 4.5$ for protein precipitation) are shown in Table 4. PC had $86.22 \%$ protein content and POC showed $38.04 \%$ protein content. Lower ashes, carbohydrates, and moisture and higher lipids were observed in PC than in POC.

$\mathrm{Yu}$ et al. (2007) reported that the proximate composition of peanut protein concentrates is influenced by the type of peanut flour used. The peanut protein concentrate obtained from roasted peanut flour exhibits higher protein $(85.67 \%)$ and lower fat contents $(2.9 \%)$, moisture $(2.73 \%)$, and other components $(0.55 \%)$ than the concentrate obtained from raw peanut flour $(77.8 \%$ protein, $13 \%$ fat, $4.6 \%$ moisture, and $1.86 \%$ other components). The lower protein content $(77 \%)$ of the protein concentrate prepared from raw peanut flour was probably due to a higher fat content exhibiting $17 \%$ fat in raw peanut flour and $12 \%$ fat in roasted peanut

Table 3

Concentrate and protein yields of protein extracts obtained from peanut oil-cake flour $(P)$ extracted at different temperatures. Protein extraction conditions: 10:1 water/flour ratio, two extraction stages, shaking for $30 \mathrm{~min}, \mathrm{pH} 9,25^{\circ} \mathrm{C}$, and $\mathrm{pH}$ 4.5 for protein precipitation

\begin{tabular}{cccc}
\hline $\begin{array}{c}\text { Extraction } \\
\text { temperature }\left({ }^{\circ} \mathbf{C}\right)\end{array}$ & Concentrate yield ${ }^{\mathrm{a}^{*}}$ & $\begin{array}{c}\text { Protein content in } \\
\text { the concentrate } \mathrm{b}^{\text {* }}\end{array}$ & Protein yield $^{\mathbf{c}^{*}}$ \\
\hline 25 & $17.37 \pm 0.47 \mathrm{~b}$ & $82.30 \pm 0.91 \mathrm{~b}$ & $14.29 \pm 0.21 \mathrm{~b}$ \\
40 & $20.02 \pm 0.33 \mathrm{a}$ & $86.22 \pm 0.92 \mathrm{a}$ & $17.26 \pm 0,47 \mathrm{a}$ \\
60 & $20.76 \pm 0.45 \mathrm{a}$ & $83.65 \pm 0.31 \mathrm{~b}$ & $17.35 \pm 0.30 \mathrm{a}$ \\
\hline
\end{tabular}

\footnotetext{
${ }^{\text {a }}$ Concentrate yield: $\mathrm{g}$ isolate $100 \mathrm{~g}^{-1}$ flour.

${ }^{\mathrm{b}}$ Protein content in the concentrate: $\mathrm{g}$ proteins $/ 100 \mathrm{~g}$ concentrate.

c Protein yield: $g$ proteins $100 \mathrm{~g}^{-1}$ flour.

* Means and standard deviations followed by different letters in each column indicate significant differences (ANOVA, LSD test, $\alpha=0.05$ ).
} 
flour. The fat matter in raw peanut flour could have reduced the efficiency of protein extraction due to the formation of emulsion in conjunction with protein during extraction, resulting in higher fat and lower protein contents in the final product. The ash contents in both protein concentrates were about the same but much lower than those found in flours. Decreasing ash content is expected since most minerals should be discarded in the supernatant after protein precipitation (Yu et al., 2007).

Wu et al. (2009) obtained peanut protein concentrates through different preparation processes precipitating the peanut proteins at isoelectric $\mathrm{pH}$ of 4.5. The peanut protein concentrates were called as follows: isoelectric precipitation peanut protein concentrate, alcohol precipitation peanut protein concentrate, isoelectric precipitation with alcohol precipitation peanut protein concentrate, and alkali solution with isoelectric precipitation, and showed different protein contents (72.35\%, 69.54\%, 71.49\%, and $96.65 \%$, respectively).

Jangchud and Chinnan (1999) reported $81.37 \%$ protein in peanut protein concentrated from defatted peanut flour with hexane (oil $2 \%$ ). Liu et al. (2012) reported a concentrate with $89 \%$ protein from defatted peanut flour. Johnson and Kikuchi (2004) reported $88.3-91.8 \%$ protein, $4.9-7 \%$ moisture and $2.4-3.8 \%$ ash in soybean protein isolates.

Table 4

Chemical composition (\% w/w on dry basis) of peanut oil cake (POC) and protein concentrates (PC) from peanut oil-cake (P) obtained at the optimum extraction and precipitation conditions (10:1 water/flour ratio, two extraction stages, shaking for $30 \mathrm{~min}$, pH 9, with no $\mathrm{NaCl}, 40^{\circ} \mathrm{C}$, and $\mathrm{pH} 4.5$ for protein precipitation)

\begin{tabular}{lrc}
\hline \multicolumn{1}{c}{ Component (\%) } & \multicolumn{1}{c}{ POC $^{*}$} & PC $^{*}$ \\
\hline Proteins & $38.04 \pm 0.32 \mathrm{~b}$ & $86.22 \pm 0.92 \mathrm{a}$ \\
Moisture & $5.99 \pm 0.03 \mathrm{a}$ & $4.16 \pm 0.18 \mathrm{~b}$ \\
Lipids & $2.54 \pm 0.23 \mathrm{~b}$ & $7.76 \pm 0.03 \mathrm{a}$ \\
Ashes & $8.32 \pm 0.04 \mathrm{a}$ & $1.16 \pm 0.01 \mathrm{~b}$ \\
Carbohydrates & $51.10 \pm 0.23 \mathrm{a}$ & $0.85 \pm 0.22 \mathrm{~b}$ \\
\hline
\end{tabular}

* Means and standard deviations followed by different letters in each column indicate significant differences (ANOVA, LSD test, $\alpha=0.05$ ).

Table 5

Amino acid composition expressed as relative percentages $\left(\mathrm{g} 100 \mathrm{~g}^{-1}\right.$ amino acids) of peanut oil-cake (POC) and protein concentrate (PC) prepared at optimum extraction and precipitation conditions (10:1 water/flour ratio, two extraction stages, shaking for $30 \mathrm{~min}, \mathrm{pH} 9$, with no $\mathrm{NaCl}, 40^{\circ} \mathrm{C}$, and $\mathrm{pH} 4.5$ for protein precipitation)

\begin{tabular}{|c|c|c|}
\hline Amino acid & POC* & $\mathrm{PC}^{*}$ \\
\hline Ala (Alanine) & $0.97 \pm 0.09$ & $1.20 \pm 0.16$ \\
\hline Arg (Arginine) & $0.91 \pm 0.16$ & $0.39 \pm 0.19$ \\
\hline Asx (Asparagine or aspartic acid) & $19.50 \pm 0.36 b$ & $34.41 \pm 0.41 \mathrm{a}$ \\
\hline Glx (Glutamine or glutamic acid) & $17.98 \pm 0.18 b$ & $24.13 \pm 0.22 \mathrm{a}$ \\
\hline Gly (Glycine) & $1.84 \pm 0.06 a$ & $0.50 \pm 0.09 \mathrm{~b}$ \\
\hline His $^{\text {a }}$ (Histidine) & $8.78 \pm 0.07$ & $8.64 \pm 0.06$ \\
\hline Ile ${ }^{a}+$ Leu (Isoleucine + Leucine) & $6.46 \pm 0.13 a$ & $2.04 \pm 0.15 b$ \\
\hline Lys a (Lysine) & $7.74 \pm 0.03 a$ & $2.08 \pm 0.05 b$ \\
\hline Phe ${ }^{a}$ (Phenylalanine) & $5.96 \pm 0.04 a$ & $2.15 \pm 0.07 b$ \\
\hline Pro $^{a}$ (Proline) & $0.46 \pm 0.06 b$ & $2.58 \pm 0.08 a$ \\
\hline Ser (Serine) & $2.04 \pm 0.08 \mathrm{a}$ & $1.01 \pm 0.11 b$ \\
\hline Thr ${ }^{a}$ (Threonine) & $0.20 \pm 0.03 b$ & $0.90 \pm 0.06 a$ \\
\hline Tyr $^{\text {a }}$ (Tyrosine) & $5.24 \pm 0.05 a$ & $4.17 \pm 0.07 b$ \\
\hline $\begin{array}{l}\text { Cys }+ \text { Val }^{a}+\text { Met }^{a} \\
(\text { Cysteine }+ \text { Valine }+ \text { Methionine })\end{array}$ & $21.92 \pm 0.16 a$ & $15.77 \pm 0.13 b$ \\
\hline
\end{tabular}

${ }^{a}$ Essential amino acids

* Means and standard deviations followed by different letters in each row indicate significant differences (ANOVA, LSD test, $\alpha=0.05$ ). 


\subsection{Amino acid composition in peanut oil-cake and protein concentrate}

Amino acid composition in peanut oil cake $(\mathrm{POC})$ and in protein concentrate (PC) obtained at the optimum extraction and precipitation conditions (10:1 water/flour ratio, two extraction stages, shaking for $30 \mathrm{~min}, \mathrm{pH} 9,40^{\circ} \mathrm{C}$ extraction temperature, and $\mathrm{pH} 4.5$ for protein precipitation) are shown in Table 5. Aspartic acid - asparragine (Asx), glutamic acid - glutamine (GIx), and cysteine, valine and metionine (Cys + Val + Met) were the major amino acids in both samples (PCO and PC). PC had a higher percentage of Asx (34.41\%), Glx $(24.13 \%)$, proline $(2.58 \%)$ and threonine $(0.90 \%)$ with respect to POC. On the contrary, POC had a higher content of glycine $(1.84 \%)$, isoleucine + leucine $(6.46 \%)$, lysine $(7.74 \%)$, phenylalanine $(5.96 \%)$, serine $(2.04 \%)$, tyrosine $(5.24 \%)$ and Cys $+\mathrm{Val}+$ Met $(21.92 \%)$ than PC.

Ferreyra et al. (2007) and Kim et al. (1992) also reported higher proportions in the contents of glutamic acid and amino acids in the peanut flour and peanut protein isolates, respectively. Other authors (Neucere, 1969; Dawson, 1971; Basha and Cherry, 1976; Kim et al., 1992) reported peanut seed proteins with high percentages of aspartic acid, glutamic acid, arginine and glycine and low percentages of cysteine and methionine. The contents of acid and basic amino acids correspond to $31-32 \mathrm{~g}$ and $15-16 \mathrm{~g}$ per $100 \mathrm{~g}$ peanut protein, respectively (Neucere, 1969; Dawson, 1971; Basha and Cherry, 1976; Kim et al., 1992).

\section{CONCLUSION}

The preparation of peanut protein concentrates was affected by changes in the extraction and precipitation conditions such as temperature, extraction $\mathrm{pH}$, ionic strength; and number of extraction stages, and the precipitation $\mathrm{pH}$. The extraction conditions which resulted in higher protein yield from peanut oil-cake were 10:1 water/ flour ratio, $\mathrm{pH} 9$ for extraction solution, with no $\mathrm{NaCl}$, 2 extraction stages, shaking for $30 \mathrm{~min}, 40^{\circ} \mathrm{C}$, and $\mathrm{pH} 4.5$ for protein precipitation.

The residual peanut oil-cake is a sub product of the oil extraction industry, and it could be extracted efficiently under the conditions described in this study in order to obtain a peanut protein concentrate with protein content higher than $85 \%$. This kind of protein concentrate could be a potential source of vegetal proteins with applications in different industries and processes.

\section{ACKNOWLEDGEMENTS}

We wish to thank CONICET (Consejo Nacional de Investigaciones Científicas y Técnicas) and SECYT-UNC (Secretaria de Ciencia y Tecnología, Universidad Nacional de Córdoba) for financial support and Lorenzati- Ruescht y Cia SA for the provision of the peanut oil-cake samples.

\section{REFERENCES}

Alonso ML, Alvarez Al, Zapico,J. 1994. Rapid analysis of free amino acids in infant foods. J. Liq. Chromatogr. $R T 17,4019-4030$

AOAC. (1995). Oficial methods of analysis of the Association of Oficial analytical chemist. Editor: Horwitz W. $13^{\text {th }}$ Ed. Washington, DC.

Basha SM, Cherry, JP. 1976. Composition, solubility, and gel electrophoretic properties of proteins isolated from Florunner (Arachis hypogaea L.) peanut seeds. J. Agric. Food Chem. 24, 359-365.

Cheftel JC, Cheftel, H. 2000. Introduccion a la bioquimica y tecnología de los alimentos, Vol. I, Editorial Acribia S.A., Zaragoza, España.

Conkerton EJ, Ory, RL. 1976. Peanut proteins as food supplements: A compositional study of selected Virginia and Spanish peanuts. J. Am. Oil Chem. Soc. 53, 754-756.

Dawson R. 1971. Comparison of fractionation of groundnut proteins by two different methods. Anal. Biochem. 41, 305-313.

Ferreyra, JC, Kuskoski, EM, Bordignon Luiz, MT, Barrera Arellano, D, Fett, R. 2007. Propiedades emulsificantes y espumantes de las proteínas de harina de cacahuate (Arachis hypogaea Lineau). Grasas Aceites 58, 264-269.

Fiant S, Alonso C, Fontana T, Spinazzé C, Costero D, Bonvehi L, Moroni A. 2012. Caracterización de la Producción de Maní (Arachis hipogaea)- Campaña 2011/2012. XXVII Jornada Nacional de Maní. 20 de setiembre de 2012. General Cabrera, Córdoba (AR): INTA - CIA. p. 18-19. ISBN/ISSN 1851-4987.

Gayol MF, Riveros C, Jauregui P, Quiroga PR, Grosso NR, Nepote V. 2010. Elaboration process, chemical and sensory analyses of fried-salted soybean. Grasas Aceites 61, 279-287.

Grosso NR, Guzmán CA. 1995. Chemical Composition of aboriginal peanut (A. hypogaea) seeds from Perú. J. Agric. Food Chem. 43, 102-105.

Jangchud, A, Chinnan, MS. 1999. Peanut Protein Film as Affected by Drying Temperature and $\mathrm{pH}$ of Film Forming Solution. J. Food Sci. 64, 1153-1157.

Johnson, DW, Kikuchi, S. 2004. Procesamiento para la obtención de aislados de proteína de soja. A\&G 55, 252-256.

Kim, N, Kim, YJ, Nam, YJ. (1992). Characteristics and Functional Properties of Protein Isolates from Various Peanut (Arachis hypogaea L.) Cultivars. J. Food Sci. 57, 406-410.

Liu Y, Zhao G, Zhao M, Ren J, Yang B. 2012. Improvement of functional properties of peanut protein isolate by conjugation with dextran through Maillard reaction. Food Chem. 131, 901-906.

Lopes Barbosa AC, Lajolo MF, Genovese MI. 2006. Influence of temperature, $\mathrm{pH}$ and ionic strength on the production of isoflavone-rich soy protein isolate. Food Chem. 98, 757-766.

Ma T, Wang Q, Wu H. 2010. Optimization of extraction conditions for improving solubility of peanut protein concentrates by response surface methodology. Food Sc. Tec. 43, 1450-1455.

Natarajan KR, Rhee KC, Cater CM, Mattil KF. 1975. Destruction of aflatoxins in peanut protein isolates by sodium hypochlorite. J. Am. Oil Chem. Soc. 52, 160-163. 
Neucere NJ. 1969. Isolation of $\alpha$-arachin, the major peanut globulin. Anal. Biochem. 27, 15-24.

Quinn MR, Beuchat LR. 1975. Functional property changes resulting from fungal fermentation of peanut flour. J. Food Sci. 40, 475-479.

Rhee KC, Cater CM, Mattil KF. 1973. Effects of processing $\mathrm{pH}$ on the properties of peanut protein isolates and oil. Cereal Chem. 50, 395-404.

Rhee KC, Cater CM, Mattil KF. 1972. Simultaneous recovery of protein and oil from raw peanuts in an aquous system. J. Food Sci. 37, 90-93.
Wu H, Wang Q, Ma T, Ren J. 2009. Comparative studies on the functional properties of various proteins concentrate preparations of peanut protein. J. Food Res. Int. 42, 343-348.

Yu J, Aahmedna M, Goktepe I. 2007) Peanut protein concentrate: Production and functional properties as affected by processing. Food Chem. 103, 121-129.

Recibido: 20/12/12 Aceptado: 20/5/13 